\title{
Sadr ad Dine Al Shirazi's Approach to the Quran The Perfect Wisdom in the Transcendent Philosophy(*)
}

\author{
Prof. Dr. Mahmoud Haidar ${ }^{(*)}$ \\ Academician and Researcher in Philosophical Thought
}

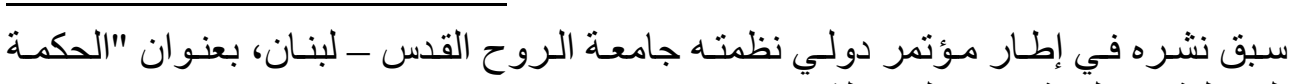

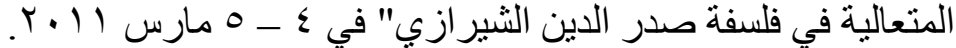

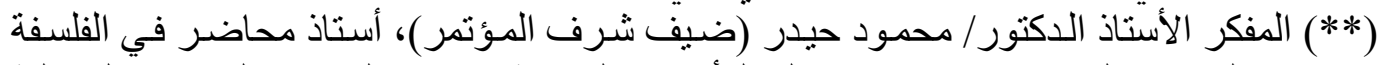

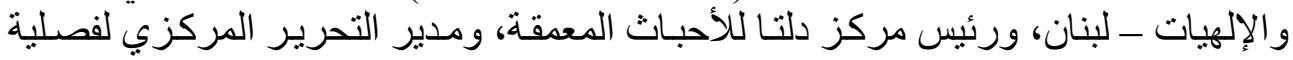


In this article, we want to shed the light on a reality that is very obvious in terms of the relationship between the Quran and the Transcendent Philosophy. To demonstrate the veracity of this matter, we refer in the first place to the continuing debate in modern philosophy which is centered on the dual concepts of the unseen and the visible, the reason and the tradition, philosophical inference and revelation not to mention science and religion.

In second place, we refer to the necessity of providing a modern analysis of the major philosophical work which Mulla Sadra excelled in elaborating its principles and foundations, the analysis being the linkage, merge and excess of the dualities of scattered statements on existence-related research.

His work entitled "The Transcendent Philosophy of the Four Journeys of the Intellect" covers all the major aspects of philosophy and theology in terms of assigning its teleological cause, that is attaining the degree of wisdom through which the sou lis prepared to ascend to the higher realm.

The Transcendent Philosophy of Sadr Al-Mutaallihin includes two stages: the first one is the knowledge of the Beginning ( $\mathrm{Al}$ Mabda') which implies the knowledge of the Names and Attributes of Allah and how the world and its order emanate from Him. The second

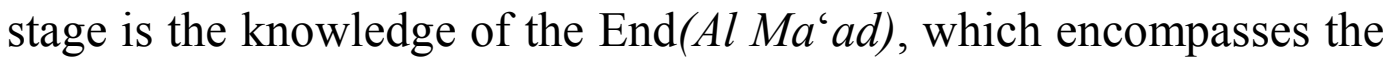
birth of the human soul, its formation from corporeal substance and eventually its progression towards its last station ${ }^{(1)}$.

The Transcendent Philosophy, thus, aims at creating a system to perceive origin of existence. This truth can be attained according to Mulla Sadra through the perception of signs and manifestations not through the essence. Some of the mystics are reported to have said: 'I knew my Lord by Himself and if not by Himself, I would not know Him.'

(1) Sadr Ad Dine Al Shirazi, Divine Manifestations (Al-Mazahir al-Ilahiyyah), Investigation by Jalal Al Din Ashtyani, Publishing Center Affiliated to the Islamic Media Office, Qom, Iran, 1419 A.H, p. 57. 
And as the intellect fails to recognize the essence of God, one shall not think about it, as indicated in this verse: "Allah warns you of Himself", and in this saying of Imam Ali (AS): ' He who searches for the essence of Allah becomes a disbeliever, and he who searches for His Attributes will be guided.'

That is why we do not find in the Quran other than pure worship and total impartiality in regard to the knowledge of God's essence, as quoted in Surat Al-Baqarah (255): 'There is no deity except Him', and in Surat As-Saffat (180): 'Exalted is your Lord, the Lord of might, above what they describe.'

Sadr Al-Mutaallihin showed that there is a consensus among the sages concerning the incapacity of perceiving the essence of the Ultimate Truth through Itself; since the Most Exalted cannot be perceived for His omnipotence and omnipresence in the world. Thus, perceiving a thing through its essence imposes limitations on it, and the Exalted God can not suffer limitation ${ }^{(1)}$.

This would lead Mulla Sadra to establish a philosophy that relies on treating the rational foundations and the theoretical principles in a wider context of thinking by resorting to the divine book, the mystical experience, the revelation and witnessing.

Such assumption will be verified within the compilation and commentaries of the Transcendent Philosophy. That is what we also found in the processes used by Mulla Sadra to reconcile the intellectual principles with the truths in the Quran and Sunnah ${ }^{(2)}$.

This reconciliation occupied a central space in the innovative work of the founder of the Transcendent Philosophy as it covers a large part of its theoretical and practical elements that range from the authenticity of existence, the morality of essence and proof based on material end.

The reconciliation of the intellect and the Sharia would be impossible without Mulla Sadra's approach to the Quran in dealing with philosophical reasoning.

(1) Divine Manifestations (Al-Mazahir al-Ilahiyyah), Commentary of Sabazdari, p. 62.

(2) Mulla Hadi Sabzawari, Commentaries on Divine Witnessings(Ta'likat 'ala Al Shawahid Al Rububyah), Introduction by Jalal Al Din Ashtyani, Dar Ehya' Al Turath Al Arabi, Second Edition, 1981, p. 11. 
For Mulla Sadra, wisdom is equivalent to Sharia. They are deeply connected and cannot be separated. Accordingly, while the theoretical wisdom (or philosophy) is considered as the knowledge of the perception of things that exist in reality, the Sharia is then viewed as the knowledge that guides to the perception of existence in virtue of the Quranic wisdom.

'And there has already come to them of information that in which there is deterrence. Extensive wisdom-but warning does not avail', from Surat Al-Qamar (2-3-5).

Therefore, we need to point out the relationship between the Perfect Wisdom and the Transcendent Philosophy. It is from here that we can notice that Mulla Sadra's philosophical thoughts marked a vivid shift in metaphysics especially when he employed the wisdom in his project as a bridge between the wisdom of nature and the wisdom of revelation.

For Mulla Sadra, wisdom is the knowledge of the realities of the world as they exist. He established a perfect ontological system and went on saying that the truth is that wisdom is existence.

The most complete method of knowledge between the acquired knowledge and the presential knowledge is the latter and the highest aspect of it is the active intellect rather than the passive one. Accordingly, God is a divine providence and the system of entities is identical to the system of Divinity.

Then, by imploring the Exalted God by the wise or by the Dua recited by the Prophet (PBUH) known as the Supplication of the Major Chain-Armour (Dua Al-Jawshan Al-Kabeer): "O Master of Perfect Wisdom", this indicates the conformation of the creation with the Truth. The Holy Quran is the unveiling of the Ultimate Truth through the world of creation by the Divine Speech revealed to the Prophet (PBUH).

It seems that the system of perception of realities in the Transcendent Philosophy is built on doctrines that are contradictory to the ones of the previous philosophical schools such as the Peripatetics, Persians,Hindus and the school of Illumination. Previously, the 
epistemological system was regarded among philosophers, especially the Peripatetics, as the images and the judgments that occur in the intellect as a result of theoretical and rational thinking. However, Mulla Sadra saw that such epistemological system is insufficient if not complemented with spiritual intuition and the illuminations of the heart which stores all the greatest knowledge.

The epistemological system of Mulla Sadra will explain a methodology that is perfectly established in order to overcome the dichotomy of the philosophical and discursive debate over the Godworld relationship.

\section{Immutability of the Perfect Wisdom:}

The impact of the Quran on Mulla Sadra planted the seeds for the Transcendent Philosophy. He wanted his work to be a philosophical reflection of the divine Speech. Thus, the Transcendent Philosophy was compared to a containerflooded with knowledge from the Quran and this container in return pours down knowledge on the world; and as much as preparation gets stronger, the knowledge extends until a new stage of perception begins through receiving more perfect wisdom.

This is to say that the epistemological system of the Transcendent Philosophy was complete due to the divine knowledge inspired from the Perfect Wisdom. According to this immutability of the perfect wisdom, Mulla Sadra established the principles and foundations of his philosophical project on the Quran.

Whereas the process of the philosophical mechanism moves upward from the lowest to the highest form of Being to understand the world as the things that exist, Mulla Sadra established an opposite methodology that consists of perceiving the existence as the only reality, moving downward from the highest form of Being to the lowest.

This is what reveals the profound difference in the processes and methods adopted in each of the acquired knowledge and the presential knowledge regarding the fundamental differencesin their introductions and results. With respect to this, we present the following: 
- It is agreed that the introductions of the acquired knowledge are based on intellectual inference that results from logical reasoning or pure concepts that are the quiddities. Thus, logically speaking, when the acquired knowledge starts with quiddities, it ends with quiddities too. From the viewpoint of Mulla Sadra, the concept of this knowledge is encompassed by the boundaries of potentiality or the vertical order of being.

- However, the introductions of the presential knowledge rely on seeking the perception of the reality of the world by connecting to the world of Kingdom, that is from the highest form of Being to the lowest. This is the methodology that Mulla Sadra adopted in his Transcendent Philosophy in order to attain its ultimate goal through the purification of the inner-self, the cleansing of the heart and the illumination of the soul.

Nevertheless, it is necessary to note that proving the existence in virtue of the presential knowledge is individual from the part of the person who is proving it. For this person, existence is real, perceptible, sensible and sentimental and he is able to prove it to himself yet unable to prove it to others; he cannot transmit the experience of unveiling through rhetoric demonstration to others and as a consequence, others cannot realize it through real, sensible and sentimental perception unless they experience direct witnessing

In his Transcendent Philosophy, Mulla Sadra synthesized the knowledge of quiddities and its realities with the presential knowledge. Thus, the Transcendent Philosophy progressed in a three-dimensional movement that begins from the divinity to the nature then returns to the divinity.

The Four Journeys of the Intellect establish these dimensions on the principle of the procession from unity to multiplicity and then returning back to unity. Accordingly, everything in existence becomes original and real.

- Unity exists (reality)

- Multiplicity exists (reality)

- The manifestation of unity in multiplicity (reality) 
- The return of multiplicity to unity (reality)

The notion of unity and multiplicity was the result of Mulla Sadra's philosophy when he saw that wayfarers among the mystics and followers of God possess four journeys:

- The first of them is the journey from creation to God

- The second of them is the journey in God with God

- The third journey is the opposite of the first because it is from God to creation with God

- The fourth is the opposite of the second in a sense because it is with God in creation ${ }^{(1)}$.

On the other hand, the practical phases of these journeys proceed in the same manner as the path and spiritual wayfaring guided by the Quranic verses. Thus, he proposed four behavioral stages:

- Al Takhliya (purification): cleaning oneself of sinful behaviors

- Al Tajliya (illumination): strictly adhering to the Islamic laws

- Al Tahliya (sweeting): beautifying oneself with the perfections of the Absolute Beautiful

- Al Fana (annihilation): Gnosticism, dissolution in the Beloved; it is the last journey towards Divinity

\section{In the reconciliation of the two wisdoms:}

As previously stated, the methodology adopted in philosophy is based essentially on demonstration considering that philosophy is the knowledge of existence through reason and not in the absolute. As a consequence, the certainty of a philosophical issue does not depend only on the observation of the content of the issue that deals with an ontological problem but relies as well on the method employed to prove the certainty of such issue.

Thus, a philosophical issue that deals with an ontological problem should not be considered valid unless it has been proved through logical demonstration.

(1) Mulla Sadra, The Transcendent Philosophyof the Four Journeysof the Intellect (AlHikma Al-Muta'alyah fi Al-Asfar al-Araba'ah), Volume 1, Introduction by Sayyid Mohamed Khamenei, Investigation by Dr. Ghulam Rida A'wani, Tehran, National Library, p.18. 
Therefore, the issue that relies on the revelation or on the experience attained through mystic unveiling should not be considered as a substitute for philosophical inference or any of its premises even if the issue of revelation would be more certain than that of the philosophical inference or any of its premises ${ }^{(1)}$.

Such proposition paves the way for attempts of reconciliation of the different views on this everlasting debate. That is the objective of the Transcendent Philosophy despite the continuing debate over this issue.

In the field of the debate between the Quranic wisdom and philosophy, the following question has been raised:

'Does the methodology adopted in the Transcendent Philosophy rely on demonstration like all the other systems in the Islamic philosophy?'

The response, as presented in the Transcendent Philosophy, is that logical demonstration does not only represent a sure way to obtain a certain judgment nor a satisfying way to attain the truth and the reality: "Demonstration is a reliable tool that leads to realize the truth"(2). "The reason is the basis of tradition, thus slandering the reason to rectify the tradition means slandering both of the reason and the tradition. ${ }^{(3)}$,"

In virtue of this, the outcome of mystic unveiling is not considered as a basis for philosophical reasoning unless it is being inspired by a corresponding intellectual inference; yet the complete unveiling in pure intellectual issues can't be proved except through inner intuition as well as logical demonstration. What is meant here by the inner intuition is the outcome of intellectual and religious practices as well as theoretical and practical endeavors.

Another question has been raised in this regard:

(1) Abdel Rassoul Oboudit, The Philosophical System of the School of Transcendent Philosophy (Al Nitham Al Falsafi li Madrasat Al Hikma Al-Muta'alyah), Part 1, Translated into Arabic by Ali Al- Mussawi, Revised by Khanjar Hammyeh, Markaz Al Hadara li Tanmyat Al Fikr Al Islami, Beirut, 2010, p. 99.

(2) Al-Asfar, Part 5, p. 91.

(3) Also see, Al-Asfar, Part 3, p. 475; p. 108; Part 5, p. 33; p. 296 and p. 91. Rissala fi Al Huduth, p. 52; Sharh Al Hidaya Al Athirya, p. 278; Sharh Usul Al Kafi, p. 294. 
'Is Mulla Sadra able to bring harmony between intuition and demonstration in his philosophical works that contain a plenitude of verses from the Quran and sayings of Gnostics and Imams as well witnessing experiences?'

Mulla Sadra, himself, used to refute a philosophy whose principles do not conform to the Quran and the Sunnah. ${ }^{(1)}$

On the other hand, Mulla Sadra refused to attribute the aspect of wisdom to the philosophy that does not rely on revelation. For him, a philosopher is not considered wise unless he attains the degree of wisdom because 'the reality of wisdom can be only attained through the Divine knowledge. Without the soul having reached this degree, it would not become wise ${ }^{(2)}$,

Does this matter drives us to consider that while the Transcendent Philosophy relies on revelation and unveiling, it does not acknowledge the method of demonstration as the basis of philosophy?

The answer is no, because benefiting from such type of issues in the Transcendent Philosophy does not contradict with the above mentioned method. Similarly, the method of demonstration does not completely exclude the benefit of the experiences of revelation and unveiling in a philosophical discourse but does not also completely give them precedence.

This way serves to identify the truth or the falsehood of the issues.

Accordingly, it is not right to consider the revelation as a substitute for logical demonstration or any of its premises and it should not be used as a methodology that serves to verify the certainty of philosophical issues or even as a substitute for intellectual criticism.

Thus, seeking reference from the sayings of the sages in the Transcendent Philosophy or in any other philosophical system does not constitute an opposition to logical demonstration unless it is used as the only reference ${ }^{(3)}$.

(1) Al-Asfar, Part 8, p. 303. Also see: Op. cit., Part 5, p. 205-206; Op.cit., Part 7, p. 326327; Op. cit., Part 8, p. 303; Mafatih Al Ghayb, p. 143; Al Mabda' wal Muad, p. 4: "I saw the compatibility between rational sources and transmitted sources, and I noticed the conformity between laws of wisdom and religious principles".

(2) Mafatih Al Ghayb, p. 41. See also: Al-Asfar, Part7, p. 326: "Mere research without mystical unveiling is a great lack in the process"

(3) Abdel Rassoul Oboudit, Op.cit., p. 101-102-103. 


\section{The Proof of God's existence:}

For the sake of inquiring about the reality of existence, Mulla Sadra pondered over the epistemological studies. He was inspired by the divine Speech and the Sunnah of the Prophet (PBUH) and the transmitted stories of the people of the Household in order to establish a proof that demonstrates the existence of the Creator without the intermediation of the creation.

This is what was known as the 'Proof of the Righteous'.

Both of the philosophers Al-Farabi and Ibn Sina first presented this proof but did not consolidate or elaborate it the way Mulla Sadra did. This proof was a fundamental element in his philosophical system.

The "righteous", as designated, are the few individuals who believed that when they contemplate the existence, they see the Ultimate Truth before any other thing. They do not only perceive or know the Ultimate Truth through imagination and meditation but also witness His existence.

The righteous ought to choose between the knowledge acquired through mere meditation and the witnessing experienced through inner revelation; and since they are in favor of the second choice, their reliance on direct witnessing and inner revelation will find its way through the Quranic verses as they begin their first journey towards the Truth.

As we see in the Quran, the Exalted God positioned the state of the righteous directly after the state of the Prophets as indicated in Surat Al-Nisa' (verse 69): 'Those will be with the ones upon whom Allah has bestowed favor of the prophets the steadfast affirmers of truth, the martyrs and the righteous. And excellent are those as companions.'

Relying on the verses of the Quran, the "righteous"are inspired by the knowledge revealed to the Prophets, the faithful and the Imams.

Lots of sayings were mentioned in this regard such as in the following hadith: 'He who knows himself knows his Lord', and in this supplication : 'He who demonstrates His essence by His Essence' and 
in the saying of Imam Ali (AS) in Nahj Al Balagha: 'When we say He is unique, we say $\mathrm{He}$ is separate from His creatures; this separation rests on the separation of Attributes and not in Entity so that His Being would be finite' or 'I knew you by You, You have guided me to You' and ' I have not seen a thing unless I have seen the Lord before, after and within it. ${ }^{,(1)}$

On the level of the intellect, the Proof of the Righteous shows that the existence of God is self-evident and does not require any demonstration. Thus, the issue of God's existence is a prime issue.

What Mulla Sadra achieved in his search to find a special proof to demonstrate his Transcendent Philosophy was a result of many investigations he carried out with philosophers, theologians, Sufis and Gnostics.

That is the reason why his method was distinct from the other ones as it synthesized the principles drawn from unveiling and witnessing with rational thinking and intellectual logic.

In consequence, his work 'The Transcendent Philosophy' embraced the most perfect theoretical proofs along with the most exceptional principles drawn from the unveiling. Thus, complementing these two forms of knowledge is the ultimate purpose of Mulla Sadra as shown in the introduction of his treatise entitled 'The Divine Witnesses'.

After all, the accomplishment of the perceptive faculty and its purpose rests in representing the rational soul in the image of the existence and the ontological system,thus, turning it into an intellectual world parallel to the real world and similar to the ontological system.

The truth is that the conception of the existence as it is, enables the soul to gain forms from things and to perceive all the realities; rather the human soul becomes according to the Transcendent Philosophy 'united with the realities in existence in virtue of the unification of the Intellect and the Intelligible. ${ }^{(2)}$

(1) Peak of Eloquence (Nahj Al Balagha), Arranged by Wajih Labib Baydoun, p. 153.

(2) Mulla Hadi Sabzawari, Commentaries on Divine Witnessings(Ta'likat 'ala Al Shawahid Al Rububyah), Commentary and Introduction by Jalal Al Din Ashtyani, Dar Ehya' Al Turath Al Arabi, p. 15. 
Such wisdom, as indicated by Mulla Sadra, appears in the supplication of the Prophet (s): 'Dear God show us things as they really are.' It also appears in the supplication of Prophet Ibrahim (PBUH): 'O my Lord, bestow wisdom on me!'

The wisdom sought after in the supplication of Prophet Ibrahim (PBUH) is the belief in the existence of things that can be conceived.

This process results in performing good deeds in order for the soul to attain a lofty state above the body, as the latter remains in a compulsive and submissive state while the former enjoys its transcendent state.

In this regard, the founder of the Transcendent Philosophy quoted from the Quran: 'We have certainly created man in the best of stature', in a reference to the image of man which is from the world of Command; 'Then we return him to the lowest of the low', in a reference to the dense and material substance of the human body; 'except for those who believe', referring to the purpose of the theoretical wisdom; ' and do righteous deeds' referring to the completion of the practical wisdom ${ }^{(1)}$.

At this point, the perfect soul would be drowned in the vastness of the Perfect Wisdom wherein it receives what strengthen the heart and purifies the soul.

\section{Path and spiritual wayfaring:}

Having established his philosophy on the Proof of the Righteous, Mulla Sadra concluded that the path and spiritual wayfaring driven by piety is a sine qua non to attain the knowledge of Tawhid (Oneness).

For Mulla Sadra, some of the most important elements that are essential to the perception of realities are the following: strengthening the practical intellect, perfecting the soul through worships and spiritual practices, abstaining from the earthly pleasures, avoiding the sinful acts, purifying the soul, reinforcing the foundations of knowledge and preparing the soul to receive the lights of Divine Knowledge.

(1) Ibid., p. 16. 
Hence, the intellect is unable to ascend to a certain degree in the comprehension of issues related to theology and the knowledge of the Beginning and the End if it is not enlightened by the Quran.

The perception of such issues through theoretical knowledge alone is not possible even if the person possesses the highest degree of perception (....) This explains why the necessity of piety in the Holy Quran was a condition to reach the perception of the Divine realities. 'Fear Allah. And Allah teaches you (...)'

Thus, Mulla Sadra embarked on his discovery and experiments in order to deduce the principles and foundations of the knowledge of the Beginning and the End. This is what he demonstrated in his books as he has inspired from the knowledge and truths he acquired from the lamp of Prophethood and Devotion.

To demonstrate the ultimate goal of his philosophical project, Mulla Sadra espoused the path and spiritual wayfaring according to the movements of the journeys of the intellect.

This manner does not differ nor break the strong link between the three structures of the Transcendent Philosophy that are the Quran ( $\mathrm{Al}$ Quran), the Demonstration (Al-Burhan) and Mysticism (Al-Irfan).

As such, he deduced the principles that embrace the movement of the path and spiritual wayfaring:

- the wayfarer exists

- and the path exists

- and the wayfaring exists

- and the aim of the path exists

Accordingly, the wayfarers verify the trueness of their spiritual wayfaring when they perceive God through direct witnessing and know that $\mathrm{He}$ is the Necessary Being, 'He who demonstrates His Essence by His Essence.'

The Proof of the Righteous is then a proof that is originally attributed to the presential knowledge. Perhaps, for this reason Ibn Sina stated that "This movement is not the means by which one proves the existence of the Truth which is the beginning of all things..." 
In his comment on the Proof of the Righteous presented by Ibn Sina, Mulla Sadra stated that "the spiritual wayfaring is the closest path to the righteous because the Transcendent Philosophy looks into the reality of Being while Ibn sina's philosophy looks into the concept of Being."

This means that the philosopher is viewed as the one who seeks the knowledge of Certainty however the aim of a wise mystic is the Eye of Certainty.

\section{The Perfect Wisdom in the Exegesis of the Quran:}

The wise theologian Sadr ad Dine Al Shirazi brought an unprecedented insight in dealing with the hermeneutics of the Quran. In the post tenth century A.H., the era during which he lived for around 75 years, apparently no other philosopher preceded him except for those who analyzed his texts and either explained, interpreted or criticized some of his ontological thesis.

Nevertheless, they could not extend beyond the epistemological foundations which Mulla Sadra established in the Middle Ages and which are still running in the Islamic philosophical thinking until today.

In this regard, one should mention that the Sadrian philosophy was unique since it was then the new philosophical product of the century and the centuries that preceded. Even some went on to describe it as a typical representation of 'the post-modernity of the Islamic civilizations.'

Since each civilization possesses a period of modernity and postmodernity, Mulla Sadra had to surround the mystics with both periods within his achievement.

The philosophy of Mulla Sadra was particular because of his criticisms of other philosophers and his transcendent ideas especially in the 'Transcendent Philosophy'. Thus, his interpretation of the Quran will be viewed as the peak of his philosophical thinking.

Although many readers of Al-Asfar (the Four Journeys) expressed their confusion towards its paradoxical aspect for having unlimited references to the Sharia and the states of wisdom, they considered it, however, as an exceptional epistemological achievement in theology. 
In this regard, the Sadrian text is considered as a text that identifies with multiple texts and contradicts them at the same time, as if Mulla Sadra implicitly reveals that he does not want to attribute anything new to himself especially when dealing with the divine Speech.

It's undeniable that the founder of the Transcendent Philosophy is proud of the superiority of his thoughts and achievements which he thinks none has accomplished before. This is what keeps him away from the effect of the post novelty which makes innovators preys of their egos that drive them to claim their own creation and originality.

However, what strikes most about Mulla Sadra is that as soon as he claims that he is the innovator of this or that idea, he immediately attributes it to his inspiration from the Divine Throne, as he considers it a grant from God.

Thus, he contents himself with playing the role of the mediator to manifest the path of the Four Journeys of the Intellect upward and downward between the Truth and the creation.

In this way, Shirazi succeeded in the reconciliation of history and metaphysics as he employed the thoughts of prior philosophers, reported their sayings, explained them and then criticized them.

That is the reason why his works were of great significance notably when he criticized some of the biggest philosophers such as the master of masters Ibn Sina, Suhrawardi and the Peripatetic philosophers.

However, rather than bounding his imagination and thoughts, Mulla Sadra worked towards opening to new horizons beyond the matter as he attributed his innovative achievements that range from the illuminations in the field of the primacy of Being to the substantial motion and many others to the Higher Self from which he was inspired.

What was previously stated is a type of reading that takes its empirical course in the field of modern interpretation in view of the approach of Mulla Sadra to the Quran. However, such type of new reading cannot encompass the principles of the Transcendent 
Philosophy unless it has been approached to the divine Speech. The Quran, according to the Sadrian exegesis, is not just a modality listed among the epistemological structure of the Transcendent Philosophy; rather the Quran encompasses all the modalities of the Transcendent Philosophy and surrounds it in all angles, and at the same time pours down on it the knowledge of Existence, and guides it.

Moreover, the Quran reflects and encompasses all the ontological degrees and represents the all-inclusive reality of existence as quoted from Surat Al-Kahf (49): 'What is this book that leaves nothing small or great that it has enumerated it?'

The Sadrian exegesis is characterized by the aspects of 'inclusion and unity' unlike the currents and schools of the post-modernity period which were marked by division and fragmentation. The aspect of inclusion which is inspired from the Quran has always been present throughout the ontological statuses of the Transcendent Philosophy on all its different degrees.

Establishing the structure of interpretation on the ground of the Transcendent philosophy requires abandoning the self that is afflicted with polytheism. However, if the personal self turns inward to itself and stays immersed in ego-centricity, it will produce its own speech.

As long as it speaks for its own sake, it fails to establish a deep intimate connection with the Speech of God who shares no partner. Thus, a major difference can be spotted here as for the principle of polytheism.

Sadr Al-Muta'allihin would have failed to achieve reconciliation between philosophy and Sharia without his reliance on the Quran. Thus, he promoted a new philosophical system in order to overcome this dichotomy. He established in his book 'the Four Journeys of the Intellect' a new methodology that opposed the views of his preceding philosophers and his contemporaries such as the Peripatetics, the Sufis and the followers of the 'Master of Illumination'. So instead of proceeding from the personal self which leads him to destruction, Mulla Sadra proceeded from The One God, the Pure Being. 
Every concept that illuminated the sky of the Transcendent Philosophy was inspired and guided by the divine Speech that lights up the path of the traveler towards the Truth. Accordingly, if we refer to Surat Al-Tawhid (Al-'Ikhlas) that states: "Say, He is Allah", we find a divine command imposing pure monotheism. The condition of monotheism is achieved when the ego-centricity of the individual self is abandoned, or else polytheism occurs.

Thus, the concept of moving from duality to oneness and from multiplicity to unity lies in the imperative form of this expression. In other words: do not say I, 'say He is Allah' which shows a negation and an affirmation. The imperative form is thus asserting the Oneness of God.

In addition, monotheism appears in a large number of the Quranic verses. Only a few examples are given here:

Surat Al-Qasas (88): 'And do not invoke with Allah another deity. There is no deity except Him.'

Surat Al-Anbya' (108): 'Say, 'It is only revealed to me that your god is but one God.'

Surat Al-Nahl (51): 'And Allah has said, 'Do not take for yourselves two deities. He is but one God.'

For Mulla Sadra, the annihilation of selfhood constitutes the initial steps for the reflection upon the divine Speech. Perhaps he perceived through his rational and intuitive experiences that the presence of the self in these experiences only leads to the concealment of the truth by imposing a veil. In consequence, the ignorance is perpetuated and the heart stays aloof from the essence of the Quran. However, Mulla Sadra's reliance on the Quranic verses led him to go far in pursuit of self-annihilation and perhaps his intellectual travel through the four journeys would open for him new horizons to the transcendent interpretation.

In his major philosophical works entitled: 'Divine Manifestations', 'Keys to the Unseen' and 'Divine Witnesses' we will clearly notice the efforts of Mulla Sadra. 


\section{Principles of Mulla Sadra's Exegesis:}

In his attempt to decipher the doctrines of exegetes, Mulla Sadra sought to demonstrate that if the personal self remains attached to the material world, it will eventually be immersed and drowned in the sea of ignorance and obscurity.

In his book 'Keys to the Unseen' (Mafatih Al Ghayb), Mulla Sadra observes four different methods of approach to the commentary on the Quran:

- the methodology adopted by the linguistics.

- the methodology adopted by the exegetes who invalidate the words from their literal meanings.

- the methodology which is a mixture of the above methodologies.

- the methodology adopted by those firmly rooted in knowledge.

Mulla Sadra adopted the methodology of those firmly rooted in knowledge whose vision is perfectly illuminated with the light of the Divine Being as they perceive Him everywhere in existence without lack or doubt. Because God has opened their heart to Islam and illuminated their spirit with faith. They perceive what no other can perceive and hear what no other can hear.

They neither disdain nor compare God and they do not balance between the two. They transcend the duality. ${ }^{(1)}$

The interpretation of Mulla Sadra bears upon the characteristics of the path of those firmly rooted in knowledge. His interpretation which brought new innovations in the field of exegesis consisted of extracting the paragraphs of the Quranic text through a continuous and perpetual study of the processes of comprehension.

For Mulla Sadra, the interpretation is based on three mechanisms which are the text, the intellect and the revelation; a method which none of his contemporaries adopted in their interpretations.

As there has been a debate over the definition of interpretation, Mulla Sadra considered the interpretation synonymous to the exegesis however the former implies a continuous and perpetual efforts in order to grasp the true meaning behind the Quranic verses.

(1) Mulla Sadra, Mafatih Al Ghayb, p. 153. 
In the viewpoint of Mulla Sadra, such method of interpretation (the perpetual exegesis) encompasses principles and disciplines, some of which are exclusively mentioned below:

- refuting the methods of exegesis that consist of separating the word from its meaning.

- joining the literal word with its exoteric meaning and the exoteric meaning with its esoteric meaning so, it goes on until revelation is attained.

- refuting both the literal and figurative meanings in the course of explaining the explicit and equivocal verses since there is a connection between the literal and figurative meanings. After all, the Quran reveals the apparent and true words of God.

Mulla Sadra held a distinct perspective regarding the explanation of the Quran because the exegesis for him, is the act of seeking a true understanding of the divine Speech. Thus, we can call his method 'the collective interpretation'.

The 'collective interpretation' is the type of exegesis that gathers the principles of various methodologies, mechanisms and strands of interpretations in order to make use of them altogether without being limited to any.

In fact, that was not what Mulla Sadra deliberately aimed at .Yet the purpose behind gathering these elements is to extract the points of similarities and resemblance between them and then contradict them altogether without rupture.

However, he proceeded in the pursuit for what he called 'the transcendent gathering'

Therefore, there will be neither a complete separation nor a complete connection in what he gathered but rather a paradoxical relation that goes beyond partiality, limitation and deliberation to establish its foundations on the Perfect words of God.

This is exactly what we will discuss in view of the concept of exegesis which supposes according to Mulla Sadra the understanding of the very divine Speech and the disciplines of the complete knowledge. 
Maybe this is the reason why his religious writings and his Hermeneutics on the Quran reflected somehow his philosophy (...)

For instance, his book entitled 'Keys to the Unseen' ${ }^{\text {(1) }}$ is the outcome of many unified elements which merged into one whole structure and which were concluded from the philosophies of the Peripatetics and the school of Illumination as well as the Gnostic experiences, the religious facts not to mention the discursive opinions and exegesis of scholars such as Al-Ghazali and Al-Razi. Mulla Sadra also borrowed in his book some of their opinions as well as other philosophers and Gnostics point of views.

In this regard, his book 'Keys to the Unseen' is viewed as a summary of what the Transcendent Philosophy aimed at in its pursuit of reconciling the intellect with the Sharia and identifying the Quran with existence as well as harmonizing philosophy with religion.

The 'Keys to the Unseen' is according to Muhammad Khwajawi, a type of book that belongs to the practical philosophy while retains at the same time the principles and foundations of the Transcendent Philosophy ${ }^{(2)}$.

In the process of establishing the principles of the recitation of the Quran, Sadr al-Mula'allihin was taking into consideration that the Revealed Book represents a version of existence. Thus, the principles and disciplines of the Quran are identical to those of existence. That is why the Quran was described by God, the Exalted as "the Wise Book, the Preserved Book, the Clear Book" and was attributed with the Beautiful and Glorious Names.

From the point of view of Mulla Sadra, the exegesis of the Quran is the explanation of existence and the keys of the Quran are the keys of the existence.

In this way, we will see how Mulla Sadra resorted to the disciplines of the recitation of the Quran while relying on reflection, revelation and knowledge. In his book 'Keys to the Unseen', he discussed the intellectual, ethical and disciplinary principles and

(1) Shirazi, Mafatih Al Ghayb.

(2) Shirazi, Mafatih Al Ghayb, p. 56. 
conditions that are necessary to follow in order to understand the divine Speech.

These principles and conditions were mentioned in Mulla Sadra's book within 10 measures that pertain to the path and spiritual wayfaring:

First: Understanding of the divine message in the Quran.Mulla Sadra invites every reciter to contemplate the favor and mercy of God and how He was gracious to His people in making His Speech able to reach their understandings and tastes, and how He pulled them towards Him with the rope of the Great Quran by means of voices and letters which are attributes of human.

Second: Purification of the heart from malicious sins and corrupted beliefs with reference to the Quranic rule in Surat AlWaqi'ah (verse 79): 'None touch it except the purified.'

Third: Presence of 'heart' and refraining from the inner chattering of the ego while reciting the Quran. This quality is born when the 'heart' is purified from the goals of one's ego.

Fourth: Reflection on what one is reading (in the Quran). It is reported that Ali Bin Abi-Talib (AS) said: 'There is no good in any worship if there is no insight into the intention behind it (fiqh) and no good in the recitation of the Quran without reflection on it.'

Fifth: Deduction; it is seeking the clarification from every divine verse what is appropriate to it, for there is not a single domain of knowledge whose principle and its derivative, its origin and end are not given in the Quran.

Sixth: Removal of the obstacles of understanding (the meaning of the Quran). This key indicates according to Mulla Sadra that there are many obstacles to the understanding of the meanings of the Quran. The heart for the perception of truths of things is like mirror for the apparition of the forms which are the objects of sight. For whenever the passion gathers intensity, the meanings of the Quran become intensely veiled. So heart is like mirror, passions are like rust, the meanings of the Quran are like forms which are seen in it. The 
discipline for the heart in order to subjugate the passions is like polish for the clarity of the mirror: 'They will only be reminded who are people of understanding.'

Sadr Al-Muta'allihin talks about four kinds of veil that constitute obstacles of understanding and urges to overcome them in order for the heart to welcome the light of the verses. These veils are the following:

1) Spending one's entire energy on the philology, grammar and syntax of the languages of the Quran.

2) Blind following of the religious doctrine heard from the Sheikhs and holding to it adamantly and becoming fanatic of it (...)

3) The third veil is the engrossment in the science of Arabic eloquence and rhetoric and going into the minutest details about the words. The basic purpose of the revelation of the Quran is to drive people to the vicinity of God by the perfection of their essences and illumination of their hearts by the light of the knowledge of God and His signs and not spending one's time to find the beautiful (word-formation) of the divine Word, the science of rhetoric, the science of figure of speech and eloquence.

4) The fourth veil is remaining firm and adhering to commentaries on the Quran given by Ibn Abbas, Qatadah, Mujahid etc. and considering any other commentary besides those as commentary according to one's own opinion. Ibn Abbas said in this concern: 'He who says something concerning the Quran without knowledge, he has taken his seat of fire.'

Mulla Sadra said that if the commentaries on the Quran were only limited to the apparent transmitted meaning, the debate would not occur between people.

Seventh: Particularity; the reciter of the Quran should perceive that the Quran is addressed to him particularly. If the Quran reveals a command or an interdiction or a promise or a threat, he should 
estimate that these states are addressed to him and should act accordingly. In this regard, we quote from Surat Al-Baqarah: 'What has been revealed to you by the Book and wisdom by which $\mathrm{He}$ instructs you'. 'This [Quran] is a clear statement to the people and a guidance and instruction for those conscious of Allah.'

Eighth: Affection and emotion. According to Mulla Sadra, this key which is essential to attain the understanding of the divine Speech is necessary in the exegesis. The reciter of the Quran should be affected by the recitation and deep reflection of the divine Speech whereby his states change according to the different types of messages in the Quran: such as sadness, fear, apprehension, hope and happiness. Thus, with threat, his fear augments and with the promise of forgiveness, he rejoices at this state and when hears the Beautiful Names and Attributes of Allah, he should bow in reverence to His Majesty and His Greatness. And upon hearing the sayings of disbelievers, he lowers his voice and gets broken inside and feels ashamed of their ugly words. And when he hears of the paradise, he feels a deep longing for it and upon describing fire, he writhes in fear (...)

The different states of the Quran by which the reciter is affected enable him to move from the stage of reciting the Quran by mouth to the stage of living the verse and experiencing himself in it. The purpose of the Quran is to elucidate these states by which the reciter is driven to the vicinity of God which is the highest level of knowledge: the knowledge of the Beginning and Divine Providence.

Ninth: The reciter should ascend to a level in recitation whereby he hears the divine Speech from God and not from himself. In this regard, Mulla Sadra mentions three levels of recitation of the Quran:

1) The person is reciting the Quran before God Who is seeing him and listening to him. The reciter should be in a state of humility and supplication. This is the lowest level according to Mulla Sadra because it includes the people who have gone beyond the apparent meaning of the verses yet have full faith in it through acknowledgment, adaptation and spiritual practices. 
2) He witnesses by his heart as if His Lord is addressing him, showering upon him His grace. The state of the reciter is that of humbleness, veneration, attention and understanding.

3) This is the highest level. In the divine Speech, he sees the Speaker, and his total energy and attention are directed to the Speaker. It is as if he is immersed in the vision of the Speaker and oblivious to everything else. About this level, Imama Ja'far Al-Sadiq (AS) is reported to have said: 'By God! God selfmanifests for His creation in the Speech, but many have no insight for that.'

Another righteous man is reported to have said: "I have not tasted the sweetness of reading the Glorious Quran until I read it imagining that the Prophet (PBUH) recited it before his companions; then I read it imagining that Gabriel (Peace be Upon Him) recited it before the Messenger of Allah (PBUH) ; then I was gifted with the highest degree. Hearing it from its Speaker, whereupon I tasted the unparalleled sweetness of reading it to the extent that I could not keep away from it.'

Here the reader attains absolute oneness as he only sees the One and All-Powerful God.

Tenth: Renunciation; according to Mulla Sadra, the reciter of the Quran should deny himself from his power and might and should look to himself with contentment and purification. When he attains this stage of self-renunciation, he can ascend to the higher one. The reciter realizes the reality of attaining this stage according to the fact that if he sees himself incapable of ascending to this stage, it is because of his ego-centricity. Thus, he who testifies farness which is the presence of the Divine within closeness, his fear lessens and he will be drawn to the vicinity of God. However, he, who testifies ego-centricity in fairness, will face deception and will be led to another lower stage.

If the reciter renounces himself and perceives only God in his recitation, the world of Kingdom will be unveiled to him. After he renounces the power and might of the Self and abandons it, he will experience unveilings according to his states. Thus if he recites verses 
about hope, he will be overwhelmed with joy and the image of paradise will be unveiled to him as if he directly witnesses it. However, if he is drowned in his sorrow, the image of hell will be unveiled to him to see its torture. The words of God are simple and kind, powerful and oppressive, promising and feared according to the states of the reciter. For God is merciful, kind, revengeful and powerful.

According to the words and descriptions, the heart changes its different states and according to each state, the reciter prepares himself for the convenient revelation as it is impossible that the state of the listener does not conform with the heard speech.

The Quran encompasses speeches that are either pleasing and furious, gracious and revengeful, compelling and majestic, sympathetic and compassionate and so on ${ }^{(1)} \ldots$

Between the Transcendent Philosophy and the Quran is a reciprocal relationship. While the principles of the Transcendent Philosophy are inspired from the Quran, the Quranic verses, employed in the Transcendent Philosophy were of great significance in philosophy and discursive thinking.

(1) Mulla Sadra, Mafatih Al Ghayb, p. 136-137-138-139-140-141. 